\title{
Ontogenetic Changes in the Hemoglobin of the Bank Vole
}

\author{
Elżbieta WOŁK
}

\begin{abstract}
Wolk E., 1983: Ontogenetic changes in the hemoglobin of the bank vole. Acta theriol., 28, 25: 387-396 [With 3 Tables \& 4 Figs.]

Two hundred and thirty-two bank voles, Clethrionomys glareolus of different age (141 wild individuals and 91 laboratory inbred voles) were typed for hemoglobin. No foetal hemoglobin was found in foetuses and newborn animals. Two basic hemoglobin bands were found in the majority of individuals from $1-8$ days old. The third, more faintly marked and with greatest electrophoretic mobility appeared in voles at the age of $9-11$ (wild bank voles) or 9-15 (laboratory bank voles) day of life. Five phenotypes (wild bank vole) and 3 phenotypes of hemoglobin (laboratory bank voles) were found among voles with the adult type of hemoglobin.

[Mammals Res. Inst., Polish Acad. Sci., 17-230 Białowieża, Poland]
\end{abstract}

\section{INTRODUCTION}

Electrophoretic studies on the biochemical structure of mammal hemoglobin, including that of rodents, have become very popular in recent years (e.g. Morton, 1966; Johnson, 1968; Selander et al., 1969, 1971; Kilpatrick \& Zimmerman, 1976; Maybank \& Dawson, 1976; Ritte et al., 1976; Stratton \& Duffy, 1976; Harleman, 1977; Hall, 1979). The hemoglobin of the bank vole, Clethrionomys glareolus (Schreber, 1780), was examined for the first time by Marchlewska-Koj (1966), and Hall (1979) demonstrated its polymorphism in Great Britain, while Fedyk \& Gębczyński (1980) considered the hemoglobin of voles from north-eastern Poland as monomorphic.

The purpose of the studies presented here was to determine the phenotypes of hemoglobin in voles of different age obtained from the Białowieża Primeval Forest, and to examine the effect of inbreeding for many generations on its genetic variability.

\section{MATERIAL AND METHODS}

Examination was made of a total of 232 hemolysates of the bank vole, Clethrionomys glareolus. The animals were caught in the Białowieża National Park (northeast Poland) - 141 individuals, or obtained from laboratory breeding in the Mammals Research Institute - 91 individuals, from the ninth to fourteenth generation of inbred bank voles (mainly eleventh and twelfth generations), originally obtained from the Białowieża National Park. The age of the animals examined varied from one day to over 2 years, and 9 foetuses obtained from laboratory 
voles were also examined. Animals of defined age were obtained by mating voles caught under field conditions or obtained from the laboratory. All fully developed voles caught in the field were identified as adults, as were all individuals over 40 days old born in captivity.

Blood samples were obtained by suborbital puncture, using heparinized microhematocrit tubes, from voles in light chloroform anaesthesis. Each contained about $50 \mu 1$ of blood. Blood was sampled in heparinized tubes from foetuses after decapitating the animals. After being washed three times with $4 \mathrm{ml}$ of $0.9 \%$ saline, the cells were lysed in $0.25 \mathrm{ml}$ of distilled water to which 2 drops of chloroform per sample were added. The stroma of erythrocytes was next centrifuged for $10 \mathrm{~min}$ at $8000 \mathrm{rev} / \mathrm{min}$, at a temperature of $-13^{\circ} \mathrm{C}$. To each $0.2 \mathrm{ml}$ of extracted hemolysate $0.02 \mathrm{ml}$ of $2 \mathrm{M}$ saccarhose (about $70 \%$ ), and bromphenol blue as indicator, were added.

Eletrophoresis on polyacrylamid gel, at a concentration of about $7.5 \%$ was carried out either immediately, or after keeping erythrocytes in a solution of $0.9 \%$ saline at a temperature of $4^{\circ} \mathrm{C}$ for 24 hours (before hemolysis). By carrying out control eletrophoresis with the addition of DTT (Dithiothreitol) we ensured that with the procedure described above denaturation of hemoglobin did not take place.

Systems of 2 gels: densifying and dividing - were prepared after Davis (1962), cited after Maurer (1971), using tris-glycine solution as electrode buffer (pH 8.5). Electrophoresis was carried out in an apparatus with cooled chambers - the upper by means of a through flow of water, the lower cooled with ice. Strength of current: $1.5 \mathrm{~mA}$ per sample. Duration of electrophoresis: about 1.5 hours. Each sample was duplicated, transferred in amounts of $0.05 \mathrm{ml}$ of hemolysate to the tubes being fixed upringht (disc electrophoresis) on the surface of the densifying gel, by means of a microdosimeter. On completion of electrophoresis one of the pairs of electrophoregrams obtained was stained with Coomassie brilliant blue G-250 (after Reisner et al., 1975; 0.04\% Coomassie brilliant blue in $3.5 \% \mathrm{HClO}_{4}$ ) for 8 hours, then destained with the following mixture: ethanol, distilled water, glacial acetic acid. Electrophoregrams prepared in this way were kept in $7 \%$ acetic acid. Parallel to this the second electrophoregram was stained with benzidine with glacial acetic acid and hydrogen peroxide for 30 minutes, and stored in distilled water. Coomassie brilliant blue G-250 stained all proteins blue, while staining with benzidine is selective for hemoglobine.

Densitograms were made for the 42 electrophoregrams obtained, using Kipp \& Zonen DD -2 Densitometer, while the remainder were directly analyzed. The size of different hemoglobin fractions was identified on densitograms, making planimetric measurements and expressing them in percentages. The electrophoretic mobility of different hemoglobin bands was calculated by dividing the distance If a given band from the starting place by the distance from the starting place to the electrophoresis front, either directly on an electrophoregram or densitogram. Columns stained with benzidine were used for identification of hemoglobin bands. Electrophoretic activity, on the other hand, was measured chiefly on columns stained with Coomassie blue, as the bands then have sharply defined boundaries

\section{RESULTS}

From 1 to 10 bands - protein fractions - were found to occur on polyacrylamid gel stained with Coomassie brilliant blue. Only those bands which stained with benzidine were considered to be hemoglobin 
bands. In the majority of electrophoregrams of samples taken from adult animals 3 hemoglobin bands were found to occur, identified as A, $\mathrm{B}$ and $\mathrm{C}$, from the smallest to greatest electrophoretic mobility. Fraction $\mathrm{B}$ is the greatest, then $\mathrm{A}$, and least $\mathrm{C}$ (in adult voles $63.9 \%, 21.2 \%$ and $14.9 \%$ respectively) (Fig. 1, Table 1 ). Ontogenetic changes in the hemoglobin of the bank vole are discussed below.

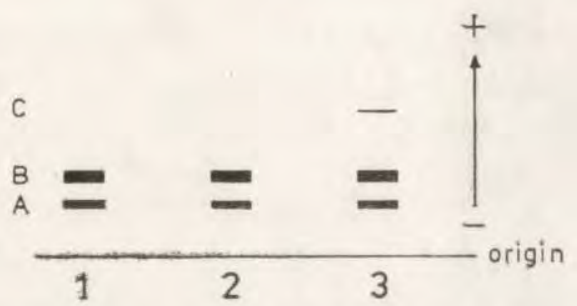

Fig. 1. Hemoglobin types of C. glareolus of different age.

A, B, C, - the hemoglobin bands, 1 - foetuses, 2 - $1-8$ day old, $3-$ adult.

Electrophoregrams of foetuses (from the second half of gestation) do not differ either in respect of the appearance of the bands or their electrophoretic mobility, from the two slower $\mathrm{Hb}$ fractions in adult individuals.

\section{Table 1}

Size of hemoglobin bands in Clethrionomys glareolus $(\%)$. Planimetric measurements on 42 densitograms made with a Kipp \& Zonen DD-2 Densitometer. Mean values and S.D. are given.

\begin{tabular}{|c|c|c|c|c|}
\hline \multirow[t]{2}{*}{ Age, days } & \multicolumn{3}{|c|}{ Size of $\mathrm{Hb}$-band $(\%)$} & \multirow[t]{2}{*}{$\mathrm{N}$} \\
\hline & A & B & C & \\
\hline Foetuses & $24.4 \pm 7.6$ & $75.6 \pm 7.5$ & - & 3 \\
\hline 1 & $26.0 \pm 6.1$ & $73.9 \pm 6.1$ & - & 4 \\
\hline $2-3$ & $18.7 \pm 8.4$ & $81.2 \pm 8.4$ & - & $4^{1}$ \\
\hline $5-6$ & $17.2 \pm 6.4$ & $82.8 \pm 6.4$ & - & $2^{2}$ \\
\hline 9 & $25.9 \pm 2.6$ & $70.2 \pm 2.3$ & $7.6 \pm 3.1$ & 4 \\
\hline $14-15$ & $21.9 \pm 3.4$ & $62.5 \pm 4.3$ & $15.5 \pm 0.9$ & 2 \\
\hline $22-24$ & $24.6 \pm 5.2$ & $58.3 \pm 8.5$ & $11.5 \pm 7.2$ & 4 \\
\hline $26-28$ & $23.9 \pm 1.7$ & $67.2 \pm 2.0$ & $8.9 \pm 2.8$ & 4 \\
\hline Adults & $21.2 \pm 4.4$ & $63.9 \pm 5.1$ & $14.9 \pm 8.9$ & $6^{3}$ \\
\hline
\end{tabular}

12 densitograms with traces of band $\mathrm{C}$ omitted,

22 densitograms omitted - with one $\mathrm{Hb}$ band and trace of band $\mathrm{C}$,

3 Only densitograms from hemoglobin type I take into conside-

ration (omitting 5 densitograms of the rarer $\mathrm{Hb}$ types).

In young voles aged from 1 to 8 days, born in captivity from parents caught in the Białowieża National Park and combined in pairs, the third hemoglobin band (C) was found to be absent, that is, the band 
with maximum electrophoretic mobility. Among the thirty individuals in this age group ( $1-8$ days old) in 26 only two basic bands (A and B) were found to be present, but in 3 samples it was possible to discern in densitograms a trace of the third band (C), which cannot be seen with the naked eye on the stained electrophoregram, and in one sample only band B. In samples from voles more than 9 days old, in which the first most common hemoglobin type had been found (see below), the third band (C) appeared (Fig. 1 and 2, Table 2). Attention must, however, be drawn to the fact that among the samples from voles 9-11 days old, out of the 12 animals examined fraction $\mathrm{C}$ was found in 8 samples, and in 4 only the two basic bands A and B. Therefore between the 9th and

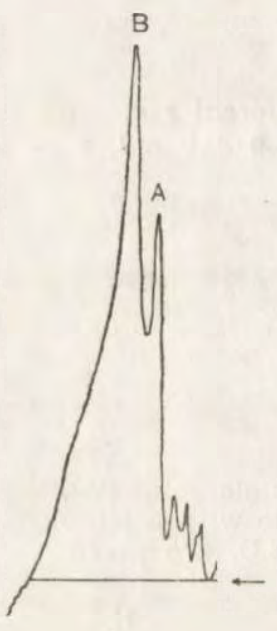

1

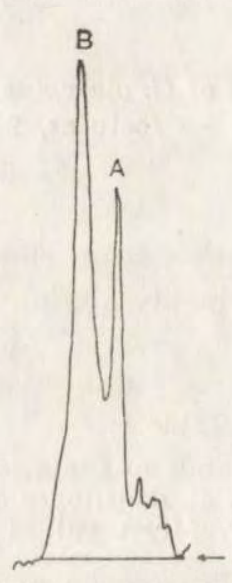

2

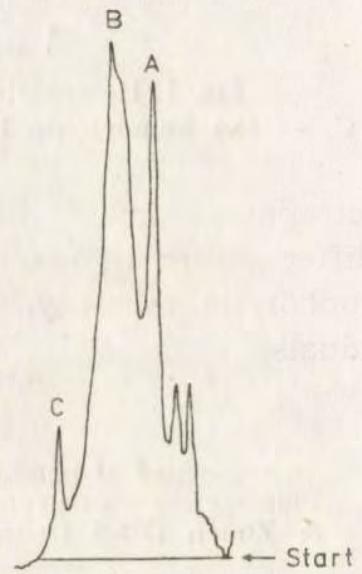

3

Fig.2. Densitograms of Coomasie blue stained hemoglobins in ontogenesis of C. glareolus.

1 - foetus, 2 - 1-day old, 3 - adult.

11th day of life of young bank voles there is a transitional period when the third hemoglobin band appears, which is proper to adult animals, although there are occasional individuals in this group with the "juvenile" hemoglobin type.

The appearance of the third hemoglobin band (C) in samples from voles bred in captivity in the Mammals Research Institute (9-14 inbred generations) is more drawn out in time than in the case of voles caught directly under natural conditions in the Białowieża National Park. This band begins to appear on the 9th day after birth in electrophoregrams stained with Coomassie blue, on the 12 th day is distinct when stained with benzidine, but even on the 15th day of life it was absent in five 
Table 2

Occurrence of hemoglobin bands in bank voles of different age.

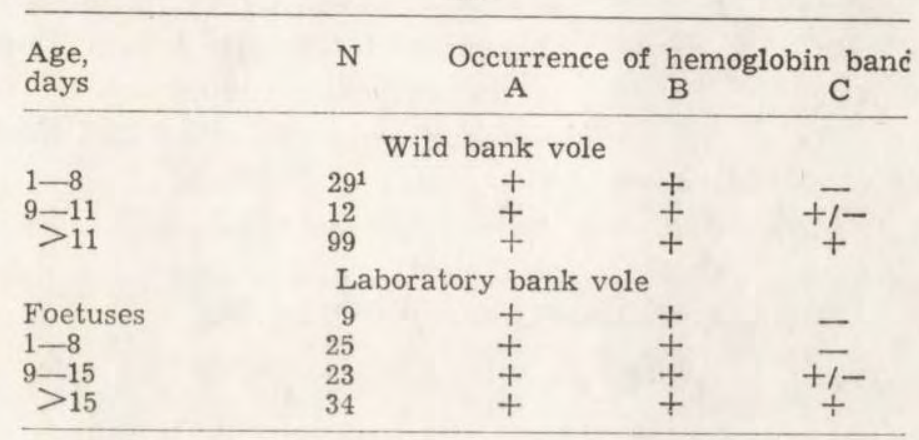

1 Without $1 \mathrm{Hb}$ type (only 1 band).

of the eight samples examined. As from the sixteenth day of life it was found in all electrophoregrams. Among the 34 individuals up to 8 day old, only the 2 basic fractions A and B were found in 32 samples, and in two samples fraction $\mathrm{C}$ was seen only as a trace in electrophoregrams

\section{Wild bank vole}

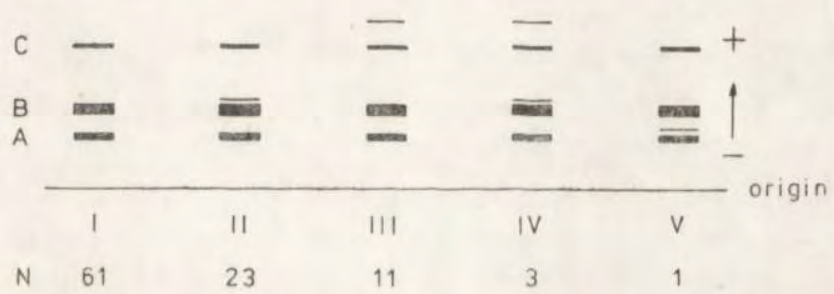

Laboratory bank vole

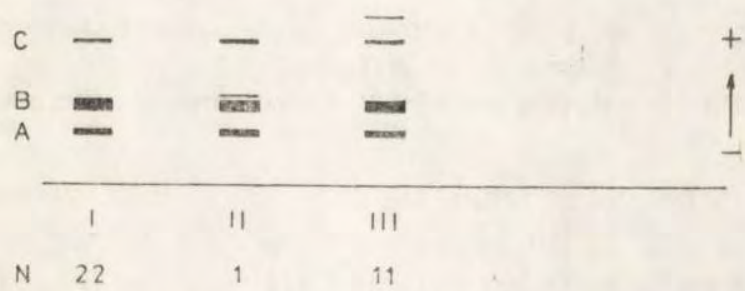

Fig. 3. Hemoglobin phenotypes of adult C. glareolus.

$\mathrm{A}, \mathrm{B}, \mathrm{C}-$ the hemoglobin bands, $\mathrm{I}-\mathrm{V}-$ different phenotypes. 
stained with Caomassie blue, but it was absent when stained with benzidine.

In 99 voles over 12 days old from the Białowieża National Park, i.e. in animals with a formed third hemoglobin band, 5 hemoglobin types were found (Fig. 3). Type $I$ is the most common, since it occurs in as many as $62 \%$ of the animals examined, while the last three hemoglobin types were only sporadically observed (Table 3 ).

Table 3

Frequency of hemoglobin types $(\%)$.

\begin{tabular}{rcc}
\hline Type & Wild bank vole & Laboratory bank vole \\
\hline I & 61.6 & 64.7 \\
II & 23.2 & 2.9 \\
III & 11.1 & 32.4 \\
IV & 3.0 & - \\
V & 1.0 & - \\
\hline
\end{tabular}

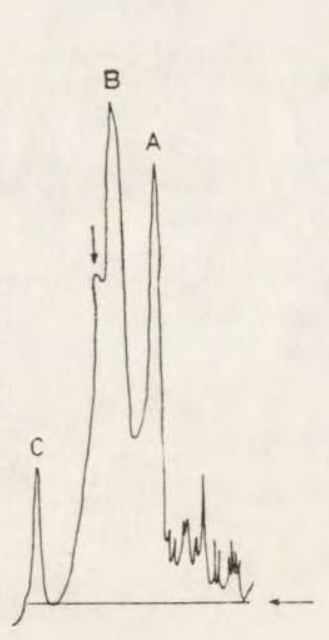

11

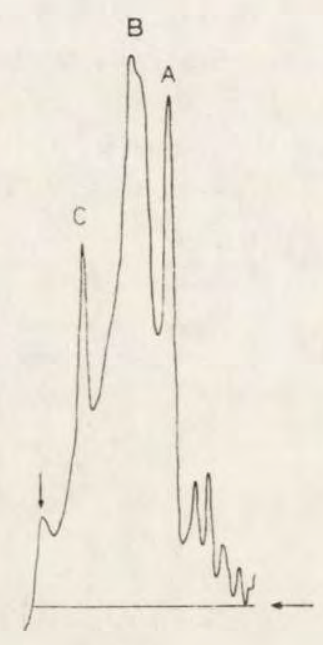

111

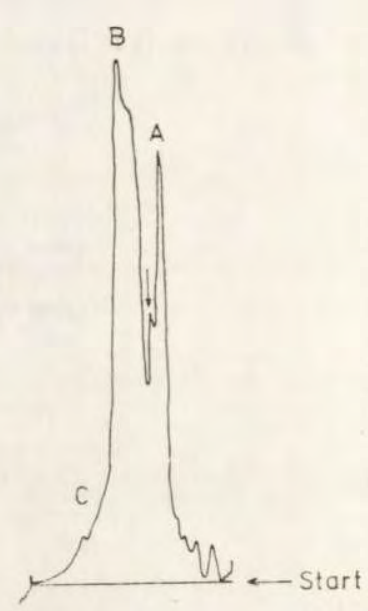

V

Fig. 4. Densitograms of some Coomasie blue stained hemoglobins of adult C. glareolus.

II, III, V - Hb phenotypes, see Fig. 3. Arrows indicate the additional bands.

In 34 laboratory voles from 16 days to over 2 years, old, that is, possessing a formed third hemoglobin band, 3 hemoglobin types were found, corresponding to types I, II and III in voles from field conditions (Fig. 4). Type I forms $64.7 \%$ in this group of voles (Table 3 ).

In tracing the size of different bands on densitograms it was possible 
to observe that band A was relatively stable $(17-26 \%$ of total hemoglobin). In addition it can be seen that as from the time at which the third band appears, i.e. from the 9th day of life, the second band decreases (Table 1).

\section{DISCUSSION}

The foetal $\mathrm{Hb}$ occurs in the majority of mammals, appearing in the second half of gestation and disappearing either before birth e.g. in Peromyscus maniculatus (Maybank \& Dawson, 1976), or during the first days of postnatal development, e.g. in Mesocricetus auratus (Irzhak \& Mojseenko, 1980). In the foetuses examined and in newborn bank voles 2 hemoglobin bands were found to occur, with the same electrophoretic mobility as bands A and B in adult voles. It would therefore appear that the bank vole can be allocated to the group of mammals (together with, e.g., the rat, Rattus norvegicus (Grigorjeva, 1980)), in which foetal hemoglobin is absent.

Hemoglobin band $\mathrm{C}$, appearing latest during ontogenetic development, can be discovered earlier by staining electrophoregrams. with a general protein stain, than with benzidine, a staining agent specific to hemoglobin. This may point to intensified hemoglobin synthesis, which is the cause of the failure to keep up with incorporation of iron into hemoglobin corpuscles. The appearance of band $\mathrm{C}$ over the space of a few days, beginning with the 9 th day of life of young voles, points to the distinct connection of this $\mathrm{Hb}$ fraction with intensified respiratory function of the animals' blood at a time which for them is a turning point, between the 9th and 15th day of life (Gębczyński, 1975). During this time stages of great importance to postnatal development take place, such as opening of the eyes (10-13 day after birth) and distinct reaction to light and sound (as from the 12th day), covering of the body with juvenile fur (up to the 10th day), eruption of the molars (as from the 10th day) and finally transition to the food typical of adult animals (as from the 15th day) (Sviridenko, 1959; Bashenina, 1972 (after Bashenina, 1981)). It is very likely that transition to an independent way of life, which is possible as from the 15th day of postnatal development, is connected with a change in hemoglobin synthesis, which may also form the cause of functional changes in the characteristics of this substance.

Thus during the development of bank voles, there would appear to be a temporary (up to the 9th day of life) blocking of the synthesis of one of the hemoglobin fractions, and consequently ontogenetic changes in the expression of one of the genes. Another interpretation of this phenomenon may be the division of the basic $\mathrm{Hb}$ band (B) into two (B and $\mathrm{C}$ ), which is indicated by the decrease of this fraction as from 
the time of appearance of band C (Table 1). It would only be possible to draw conclusions as to the correctness of either of these hypotheses after carrying out detailed biochemical and genetic studies.

The drawing out in time of the appearance of the third $\mathrm{Hb}$ basic band in laboratory voles in comparison with wild voles (Table 2), is certainly connected with the retarded transition of such captive animals to an independent way of life.

In Clethrionomys glareolus from Great Britain two hemoglobin phenotypes have been reported, each with a geographical distribution which does not overlap the other (Hall, 1979). In voles from the Białowieża National Park Fedyk \& Gębczyński (1980) observed only one variant of hemoglobin occurrence, namely three-band hemoglobin, with distribution and size of bands similar to the commonest type I (Fig. 3) On this basis they held the hemoglobin of the bank vole to be monomorphic. The above authors carried out separation of proteins on starch gel after Selander et al. (1971). In the present studies, however, 5 hemoglobin types, two of which were very rare, were found in adult voles. It may be that separation on polyacrylamid gel is a more sensitive method of electrophoretic separation of hemoglobin.

In inbred voles only $3 \mathrm{Hb}$ types were observed, which may point to selection of certain genotypes. In addition $\mathrm{Hb}$ type III would appear to be more numerous in captive voles (Fig. 3). It would undoubtedly be interesting to trace further inbred generations of laboratory voles from this aspect.

Hemoglobin is a protein coded by several loci, the products of which may enter into reciprocal combinations in the form of heterotetrameres. Hemoglobin corpuscles are in addition distinguished by considerable lability, as a result of which repolymerization may take place. Hence genetic interpretation of the data obtained from electrophoretic division of hemoglobin is difficult.

Acknowledgements: Thanks are due to Professor S. M. Klimaszewski for his kind help in making densitograms and to Mrs. S. Bogdańska for her technical assistance.

\section{REFERENCES}

1. Bashenina N. V. (ed) 1981: Evropejskaja ryžaja polevka. Izd. Nauka: 1-351. Moskva.

2. Fedyk \& Gębczyński M., 1980: Genetic changes in seasonal generations of the bank vole. Acta theriol., 25: 478-485.

3. Gębczyński M., 1975: Heat economy and energy cost of growth in the bank vole during the first month of postnatal life. Acta theriol., 20: 379-434.

4. Grigorjeva G. I., 1980: Gemoglobin krysy Rattus norvegicus i ego osobennosti. Ž. evol, Bioch. Fizjol., 16: 499-505. 
5. Hall S. J. G., 1979: Haemoglobin polymorphism in the bank vole, Clethrionomys glareolus, in Britain. J. Zool., 187: 153-160.

6. Harleman J. H., 1977: The haemoglobins types of mice. Lab. anim., 11: 105-108.

7. Irzhak L. J. \& Mojseenko N. A., 1980: Frakcii gemoglobina v postnatalnom ontogeneze homjaka Mesocricetus auratus. Ž. evol. Bioch. Fiziol., 16: 112-119.

8. Johnson M. L., 1968: Application of blood protein electrophoretic studies to problems in mammalian taxonomy. Syst. Zool., 17: 23-30.

9. Kilpatrick C. W. \& Zimmerman E. G., 1976: Hemoglobin polymorphism in the encinal mouse Peromyscus pectoralis. Biochem. Genet., 14: 137-143.

10. Marchlewska-Koj A., 1966: Studies on the electrophoretic properties of haemoglobin and plasma proteins of Microtidae $(\mathrm{Cl}$. glareolus, $\mathrm{M}$. arvalis, M. agresis). Folia biol., 14: 177-181.

11. Maurer H. R., 1971: Disk-elektroforez. Teorija i praktika elektroforeza $\mathrm{v}$ poliakrilamidnom gele. Izd. Mir: 1-247. Moskva.

12. Maybank K. M. \& Dawson W. D., 1976: Genetic and developmental variation of haemoglobin in the deermouse, Peromyscus maniculatus. Biochem, Genet. 14: $389-400$.

13. Morton J. R., 1966: The multiple electrophoretic bands of mouse haemoglobins. Genet. Res., 7: 76-85.

14. Reisner A. H., Nemes P. \& Bucholtz C., 1975: The use of Coomassie Brillant Blue G-250 perchloric acid solution for staining in electrophoresis and isoelectric focusing on polyacrylamide gels. Anal, Biochem., 64: 509-516.

15. Ritte U., Haim A. \& Neufeld E., 1976: Use of electrophoretic patterns of hemogiobin for identification of Israeli gerbils (genus Gerbillus: Rodentia: Gerbillinae). Isr. J. Zool., 25: 52-60.

16. Selander R. K., Yang S. Y. \& Hunt W. G., 1969: Polymorphism in esterases and hemoglobin in wild populations of the house mouse (Mus musculus). Studies in Genetics, V. Univ. Texas Publ., 6918: 271-338.

17. Selander R, K., Smith M. H., Yang S. Y., Johnson W. E. \& Gentry J. B., 1971: Biochemical polymorphism and systematics in the genus Peromyscus I. Variation in the old-field mouse (Peromyscus polionotus). Studies in Genetics, VI. Univ. Texas Publ., 7103: 49-90.

18. Stratton L. P. \& Duffy L. K., 1976: Hemoglobin polymorphism in Microtus pennsylvanicus. Comp. Biochem. Physiol., 54B: 413-415.

Accepted, June 6, 1983.

Elżbieta WOŁK

\section{ONTOGENETYCZNE ZMIANY W HEMOGLOBINIE NORNICY RUDEJ}

\section{Streszczenie}

Zbadano typy hemoglobiny u 232 nornic rudych, Clethrionomys glareolus w różnym wieku, z których 141 odłowiono w Białowieskim Parku Narodowym, a 91 po- 
chodziło z wsobnego chowu Zakładu Badania Ssaków w Białowieży (głównie z jedenastego i dwunastego pokolenia wsobnego). Nie stwierdzono hemoglobiny płodowej u płodów i u noworodków. U większości nornic w wieku do 8 dni stwierdzono 2 podstawowe prążki hemoglobiny A i B (Tabela 1). Trzeci, słabiej zaznaczony i o największej ruchliwości elektroforetycznej, prążek C pojawił się u nornic pochodzących z terenu między 9 i 11 dniem, a u nornic laboratoryjnych między 9 a 15 dniem życia (Ryc. 1 i 2, Tabela 2). Pojawianie się prążka C w przełomowym okresie przechodzenia nornic do samodzielnego życia wskazuje na wyraźny związek tej frakcji hemoglobinowej ze wzmożoną funkcją oddechową krwi.

$\mathrm{U}$ nornic pochodzących $\mathrm{z}$ terenu o dorosłym typie hemoglobiny wyróżniono 5 fenotypów, a u nornic laboratoryjnych 3 fenotypy hemoglobiny (Tabela 3, Rys. 3 i 4). Najpospolitszy typ I stwierdzono u ponad $60 \%$ nornic. 